dr Jacek Ladorucki

Katedra Bibliotekoznawstwa

i Informacji Naukowej

Uniwersytet Łódzki

\title{
Budowanie relacji mistrz - uczeń. O znaczeniu mistrzostwa w misji współczesnego uniwersytetu i działalności kół naukowych
}

\section{Kreowanie człowieka w jego człowieczeństwie to misja uniwersytetu}

Współczesne uniwersytety to spadkobiercy średniowiecznej idei kształcenia, wychowywania i wspólnotowości uczonych i studentów ${ }^{1}$. Ta niezwykła koncepcja na zachodzie Europy objawiła się w XII wieku, a w Polsce jest żywa od wieku XIV. Pierwszym uniwersytetem europejskim był prawdopodobnie Uniwersytet Boloński. Za datę jego powstania przyjmuje się rok 1158, w którym to cesarz Fryderyk Barbarossa obdarzył uczelnię przywilejem częściowej niezależności od władz miejskich. W Polsce Akademia Krakowska (studium generale) powstała 1364 z fundacji Kazimierza III Wielkiego i odnowiona w 1400 roku przez Władysława II Jagiełłę z fundacji Jadwigi Andegaweńskiej. W 1817 r. krakowskiemu uniwersytetowi nadano nazwę Jagielloński, dla podkreślenia jego związków z tą dynastią ${ }^{2}$. Uniwersytet jako Alma Mater - Matka Żywicielka - karmiąca nauką, od stuleci przygotowuje i inicjuje jednostki do najważniejszych ról społecznych. Dzisiejsze uniwersytety chlubią się swoim dziedzictwem i odpowiadają na liczne wyzwania społeczne, kulturowe i ekonomiczne. Większość instytucji o charakterze uniwersyteckim buduje filary własnej tożsamości i podkreśla znaczenie dla społeczeństwa poprzez wyznaczanie obszarów misji, rozumianej jako cele i zadanie do zrealizowania. Akademicy od wieków trwają przy wartościach stanowiących najwyższe ideały życia człowieka, takich jak: prawda, odpowiedzialność, rzetelność, uczciwość, konsekwencja. Umacnianie i obrona pierwiastków humanistycznych to jeden z najważniejszych celów wspomagających rozwój nauki i kształcenia studentów we współczesnym wielobiegunowym świecie.

\footnotetext{
${ }^{1}$ Łac. Universitas magistrorum et scholarium oznacza: ogół nauczycieli i uczniów.

${ }^{2}$ Zob.: Starnawski J.: Uniwersytet światyniq wiedzy, Łódź: Wojewódzka i Miejska Biblioteka Publiczna im. Marszałka Józefa Piłsudskiego, 2007, s. 5-18.
} 
Globalizacja edukacji stała się nowym wyzwaniem dzisiejszych czasów, ale odpowiednio sformułowany obszar misji pozwala uniwersytetom godzić tradycję i nowoczesność. Uniwersytet Łódzki (UŁ) chlubi się jasno nakreśloną wizją funkcjonowania uczelni, w której największą wagę przywiązuje się do pięciu głównych zadań. Przede wszystkim, jako młoda uczelnia, UŁ czerpie z tradycji wielonarodowej i wielokulturowej Łodzi, a ws póln o t a uczonych, studentów, absolwentów oraz pracowników, nabiera w takim wypadku szczególnego znaczenia. Dialog w wielokulturowym mieście zawsze musi się opierać na zasadach demokracji i humanizmu. $\mathrm{Z}$ tych ważnych dla współczesnej Europy zasad wynika także, zapisana w misji UŁ, otwarto ść. Wobec ogromnej różnorodności i złożoności świata otwarcie na jego bogactwo stanowi podstawę samoidentyfikacji. Działanie w duchu wolności badań naukowych, swobody dyskusji akademickiej i przekazywanej wiedzy doskonale rozwija kolejną zasadę funkcjonowania UŁ sformułowaną jako jedność w różnorodności. Uniwersytety, w tym UŁ, budują strategie innowacyjnego rozwoju miast, regionów i całego kraju, poszukując rozwiązań dla problemów gospodarczych i społecznych. Na przestrzeni wieków praca uniwersytetów stanowiła wyraz kondycji kultury ludzkiej. Uniwersytet Łódzki jako uczelnia współczesna realizuje misję e li ta r n o śc i kształcąc ludzi mądrych i odpowiedzialnych ${ }^{3}$. Przegląd misji czołowych polskich uczelni pokazuje, iż etos uniwersytecki jest żywy i jasno określony, choć na sposób jego realizacji ogromny wpływ mają reguły ekonomiczne i administracyjne.

Podczas obchodów 600-lecia Uniwersytetu Jagiellońskiego, najstarszej polskiej uczelni, Bronisław Geremek podkreślał, iż: „W świecie współczesnym uczyć się trzeba stale, a kilkuletnie studia wyższe stanowią tylko inicjację do ról zawodowych, jakie młodzi ludzie będą pełnić w życiu i powinny przeto uczyć uczenia się. Szkoła wyższa nie jest tylko zamknięciem cyklu edukacji młodzieży, ale także otwarciem cyklu edukacji permanentnej, której nowe technologie komunikacji służą znakomicie ${ }^{4}$. Po tych słowach wybitnego historyka i działacza społecznego, warto podkreślić, że uniwersytety od zawsze kreowały wyobrażenia o przyszłości, ale też zmagały się z otaczającą rzeczywistością. Widoczna współcześnie wszechobecna marszandyzacja stosunków społecznych ${ }^{5}$ niesie niebezpieczne zmiany modelu myślenia, ale także

3 Pełny opis misji UŁ zob.: http://www.uni.lodz.pl/ouni/misja [data dostępu: 30.11.2012].

${ }^{4}$ Cytat za: Geremek B.: Idea Uniwersytetu. Zob.: http://www3.uj.edu.pl/alma/alma/26/01/35.html [data dostępu: 30.11.2012].

5 Termin „marszandyzacja” został użyty przez francuskich badaczy: Allain Caille i Phillipe Chamail. W polskiej literaturze naukowej był przywoływany w artykule: Marynowicz-Hetka E.: Filozoficzny wymiar pracy socjalnej/społecznej (na marginesie ksiażki Lecha Witkowskiego) [W:] Witkowski L: Praca socjalna i profesjonalizm 8 
sposobu tworzenia wiedzy naukowej. Konieczność odnajdywania we wszystkim wartości cenowej i rynkowej opłacalności prowadzi do zaniku bezinteresowności i może niejednokrotnie sugerować, że tylko działania ekonomicznie uzasadnione są społecznie akceptowane i potrzebne. Gloryfikacja utylitaryzmu, produktywności, opłacalności i rentowności widoczna coraz mocniej w procesie tworzenia wiedzy naukowej prowadzi do pytań o to, czy nauka pozostaje wciąż autonomiczną częścią kultury służącą objaśnianiu funkcjonowania świata, w którym żyje człowiek? Czy nadmierne koncentrowanie się na funkcji edukacyjnej uczelni sprzyja jeszcze wypełnianiu przez nią właściwej funkcji społecznej? Komercjalizacja edukacji uniwersyteckiej i jej dyspozycyjność wobec rynku pracy nie powinna nigdy wzbudzać wątpliwości, iż da się osiagnąć sukces, zdobyć potrzebny i szanowany społecznie zawód bez ugruntowania akademickiej wiedzy w filozofii, humanistyce, kulturze i szeroko rozumianej tradycji naukowej.

\section{Koła naukowe czerpią z idei uniwersytetu i dopełniają jego misji}

Współczesne koła naukowe, organizacje zrzeszające studentów w obrębie różnego typu szkół wyższych, stanowią nawiązanie do tradycji wspólnoty i dopełniają misji uczelni. Celem tych organizacji jest działalność naukowa i samokształceniowa ich członków, ale często także budowanie relacji i powiązań między uniwersytetem a otoczeniem ${ }^{6}$.

Najstarszym działającym w Polsce kołem naukowym jest Towarzystwo Biblioteki Słuchaczów Prawa Uniwersytetu Jagiellońskiego, które szczyci się ponad 160-letnią historią. Ta niezwykła organizacja studencka skupia ludzi, którzy „postrzegają studia jako coś więcej niż monotonny rytuał zaliczania

pedagogiczny. O zarzqdzaniu humanistycznym: miedzy filozofia, edukacja i pedagogika społecznq. Łódź: Wydawnictwo Wyższej Szkoły Edukacji Zdrowotnej i Nauk Społecznych, 2010, s. 9-22.

${ }^{6}$ Znane są liczne aktywności i kooperacje kół naukowych z otoczeniem. W latach 2000-2008 Studenckie Koło Naukowe Bibliotekoznawców UŁ podejmowało się wielu działań na rzecz lokalnych społeczności. Najbardziej skuteczna była akcję edukacji informatycznej wśród seniorów oraz promocje czytelnictwa i korzystania z bibliotek skierowana do łódzkich bezrobotnych. Więcej na ten temat zob.: Ladorucki J.: Studenckie Koło Naukowe Bibliotekoznawców Uniwersytetu Łódzkiego w latach 20002008 [W:] Tradycyjne i nowoczesne bibliotekarstwo $w$ oczach studentów informacji naukowej i bibliotekoznawstwa: materiały z I ogólnopolskiej konferencji naukowej „Biblioteka: obiekt - idea wczoraj, dziś, jutro”, (Łódź, 18-19 maja 2007 r.) i I ogólnopolskiej konferencji studenckich kót naukowych „Elektroniczne oblicze biblioteki”, (Lublin, 11 kwietnia 2008 r.). red. J. Ladorucki i R. Malesa, Kraków: Wydawnictwo AT Group, 2009, s. 11-20; tenże: Koło naukowe jako szkoła twórczego działania [W:] Historia i współczesność w badaniach bibliologicznych. Pod red. J. Koniecznej, Łódź: Ibidem 2007, s. 185-189. 
kolejnych przedmiotów. To organizacja dla ludzi aktywnych, których celem jest wszechstronny rozwój - nie tylko naukowy, ale również na płaszczyźnie praktycznych umiejętności”?

Warto podkreślić, iż podstawą działania uniwersytetów i kół naukowych była od zawsze relacja mistrz-uczeń. Zastanówmy się więc nad tym, czym jest ta relacja, jaka jest jej istota i jakie ma ona znaczenie dla idei międzypokoleniowego transferu wiedzy i kompetencji?

Poszukiwanie znawstwa jest szczególnie ważne, gdy podejmujemy decyzje, których skutki zależą od trudno rozpoznawalnego stanu rzeczy. Chęć znalezienia mistrza jest czymś naturalnym dla człowieka jako istoty myślącej. W szkole, na studiach, w rozwoju zawodowym poszukujemy kogoś, kto posłuży przykładem, zmotywuje i uczyni nasze działanie łatwiejszym i skuteczniejszym. Od zawsze, aby móc pobierać wiedzę, należało znaleźć mistrza, który wprowadzał w jej tajniki i pełnił rolę przewodnika po nieznanym świecie $^{8}$. Relacja mistrz - uczeń stała się naturalną formą kontaktu przy pobieraniu jakiejkolwiek nauki. Tak było już w starożytnej Akademii Platońskiej i w późniejszych cechach rzemieślniczych w całej Europie. Z czasem pojawiło się pojęcie szkoły naukowej, tworzącej się wokół osoby mistrza. Szkoła tego rodzaju, o charakterze nie-instytucjonalnym, skupiała grupę ludzi podzielających poglądy mistrza, naśladujących i kontynuujących jego sposób myślenia i postępowania ${ }^{9}$. Relacja mistrz-uczeń kreuje pewien rodzaj symbolicznej bliskości, która odnosi się zarówno do sfery poznawczej (działaniowej) jak i emocjonalnej ${ }^{10}$.

\section{Kim jest mistrz?}

Pytanie o to, kim jest mistrz otwiera problem natury szerszej. Prowadzi bowiem do kwestii filozoficznych i metodologicznych wręcz dylematów, czy mistrz powinien tylko dbać o poziom intelektualny uczniów, czy też jego zadaniem jest wychowywanie i wpajanie studentom pewnych zasad moralnych. Rozumienie słowa „mistrz” nie jest kwestią tylko językową, ale język posiada

${ }^{7}$ TBSP UJ powstało 23 czerwca 1851 roku; prowadzi szeroko zakrojoną działalność dydaktyczną, naukową i kulturalną, każdego roku zapisuje się do niego około 300 nowych członków. Więcej na ten temat zob.: http://www.tbsp.pl/?link=onas [data dostępu: 30.11.2012].

${ }^{8}$ Mistrz - uczeń: wyobrażenia czy rzeczywistość czyli o tworzeniu szkót naukowych. Oprac. E. Marynowicz-Hetka. Łódź: Łódzkie Towarzystwo Naukowe, 1997, s. 13.

${ }^{9}$ Zobacz więcej na ten temat: Zieliński E. I.: Rola mistrza i szkoty w filozofii [W:] Spór o rozumienie filozofii. Zadania wspótczesnej metafizyki. Red A. Maryniarczyk, K.. Stępień. Lublin: Polskie Towarzystwo Tomasza z Akwinu, 2009, s. 56.

${ }^{10}$ Mistrz-uczeń: wyobrażenia..., s. 12. 
dla humanisty walor porządkujący. Rozpocznijmy więc od doprecyzowania pojęć. W języku polskim można wyróżnić 4 znaczenia terminu „mistrz”:

- W pierwszym znaczeniu pod pojęciem „mistrz” można rozumieć człowieka przewyższającego innych $\mathrm{w}$ jakiejś dziedzinie działalności. Znaczenie to jest bliskie zdroworozsądkowemu odczuciu i potocznemu mniemaniu, o wyższości ,mistrza” nad otoczeniem.

- W drugim znaczeniu określenie ,mistrz” ma charakter tytularny i odnoszone jest do zwierzchników niektórych stowarzyszeń i zakonów rycerskich. $\mathrm{W}$ podobnym też charakterze występuje w sporcie, kiedy słyszymy o „mistrzostwie świata”, ,mistrzach olimpijskich” lub czempionach (ang. champion ).

- Trzecie znaczenie terminu „mistrz” kieruje naszą uwagę w stronę pojęcia autorytetu, prestiżu i społecznego uznania opartego na cenionych w danym społeczeństwie wartościach. „Mistrz” jest w tym wypadku osobą godną naśladowania, uznaną za wzór. Łaciński auctoritas, oznaczający powagę i wpływy, definiuje zawsze traktowanie prawdziwego mistrza jako autorytetu.

- Ostatnie funkcjonujące w języku polskim znaczenie pojęcia „mistrz” związane są z pracą fizyczną i opisuje zazwyczaj wykwalifikowanego pracownika nadzorującego pracę innych robotników. „Mistrz” w tym obszarze znaczeń to także dyplomowany rzemieślnik.

W kontekście działalności uniwersytetów i kół naukowych najważniejsze jest pierwsze i trzecie znaczenie pojęcia ,mistrz”. Zatem mistrz to człowiek przewyższający innych umiejętnością czegoś, biegłością w czymś, niedościgniony w swojej dziedzinie, ale jednocześnie człowiek godny naśladowania, autorytet ${ }^{11}$. Mistrz jako autorytet występuje zawsze jako niepodważalny autor własnych działań akceptowanych na poziomie racjonalnej argumentacji. Na autorytetach spoczywa odpowiedzialność podejmowania decyzji i wyboru. Niektórzy podkreślają, iż każdy etap badań naukowych nacechowany jest ryzykiem niemniejszym niż decyzje $\mathrm{w}$ działaniach praktycznych ${ }^{12}$. Uczony-autorytet obarczony jest ciężarem pytań dotyczących ważkości podejmowanych problemów badawczych w kontek-

${ }^{11}$ Łac. magister oznacza nauczyciela, uczonego, mistrza. Termin „magisterium” oznacza naukę, biegłość, umiejętność. Przymiotnik magistralis znaczy tyle co mistrzowski, świetny, doskonały, uczony; natomiast przysłówek magistraliter oznacza: po mistrzowsku, gruntownie, biegle, kunsztownie. We wszystkich terminach obecny jest rdzeń „magis-” oznaczający: mocniej, bardziej, więcej. Zob. na ten temat: Zieliński E. I.: Rola mistrza i szkoty w filozofii..., s. 51.

${ }^{12}$ Zagadnienie autorytetu i ciążących na nim odpowiedzialności rozważa Klemens Szaniawski. Zob: Tenże: O nauce, rozumowaniu $i$ wartościach. Warszawa: Wydawnictwo Naukowe PWN, 1994, s. 104-105. 
ście rozwoju dyscypliny, kierunków poszukiwań, interpretacji nieoczekiwanych wyników, sensowności kontynuowania badań itp. Decyzje te podejmowane są zazwyczaj w warunkach nieokreślonych z góry, a przez to doradztwo w tej materii jest jedną z najbardziej odpowiedzialnych ról społecznych. Ostatecznie można podsumować - za Klemensem Szaniawskim -że rzetelny autorytet w nauce jest tym potrzebniejszy, im bardziej w danej rzeczywistości zagrożone są prawdziwe wartości ${ }^{13}$.

Literatura naukowa zawiera liczne opisy i świadectwa indywidualnego mistrzostwa profesorów minionych epok. Często charakterystyki bywają tak idealne, iż naturalne staja się pytania, ile pozostało z dawnych mistrzów we współczesnych uczelniach. Piękne testimonium ucznia o mistrzu pozostawił pierwszy rektor UŁ, Tadeusz Kotarbiński, kiedy pisał o swoim preceptorze - profesorze Kazimierzu Twardowskim:

To było najważniejsze, że działał własnym przykładem, okazując na sobie samym, jak można urzeczywistniać zalety dobrej roboty w zastosowaniu do pracy umysłowej. Był tedy wzorem solidności w dotrzymywaniu umów i terminów, wzorem planowości, wzorem systematyczności w wykonywaniu zamierzeń, wzorem człowieka, na którego zawsze można liczyć we współpracy zorganizowanej. I jeszcze jedno: cenił indywidualność $i$ umiał przystosować stawiane zadania do odrębnych zainteresowań młodych ludzi, ciesząc się rozmaitością umysłów i ich wytworów, byleby wspólnie poddawanych obiektywnym rygorom racjonalności ${ }^{14}$.

Współcześnie proces instytucjonalizacji szkolnictwa i umasowienia edukacji oznacza niejednokrotnie zanik relacji mistrz-uczeń oraz uprzedmiotowienie kontaktów pomiędzy studentem oraz profesorem. Allan Bloom w znanej książce Umyst zamknięty pisał, iż:

Nauczyciel [...] musi stale mieć przed oczyma wzorzec skończonej istoty ludzkiej, a w pamięci naturę studentów jako konkretnych jednostek, musi poddawać ów wzorzec nieustannej weryfikacji i oceniać zdolność studentów do jego osiągnięcia. Sens powołania nauczycielskiego polega na tym, by znać pragnienia swych uczniów i wiedzieć, co może je zaspokoić. Trzeba je wytropić i wydobyć na wierzch ${ }^{15}$.

Takie nastawienie wymaga podejścia podmiotowego, nakierowanego na pojedynczą osobę, a nie anonimową zbiorowość. Tymczasem współczesne uniwersytety dążą do unifikacji i schematyzacji programu studiów oraz relacji

\footnotetext{
${ }^{13}$ Tamże.

${ }^{14}$ Kotarbiński T.: Sprawność i błqd (z myśla o dobrej robocie nauczyciela). Warszawa: Państwowe Zakłady Wydawnictw Szkolnych, 1966, s. 17.

${ }^{15}$ Bloom A.: Umyst zamknięty. O tym, jak amerykańskie szkolnictwo wyższe zawiodło demokrację i zubożyto dusze dzisiejszych studentów, przekł. T. Bieroń. Poznań: Zysk i S-ka Wydawnictwo, 1997, s. 19.
} 
między wykładowcą a studentem. Powstaje więc pytanie, jakie miejsce we współczesnym uniwersytecie ma mistrzostwo w ogóle? ${ }^{16}$

Wybitny autorytet w dziedzinie pedagogiki społecznej, Ewa Marynowicz-Hetka mówi o zaniku we współczesnych uniwersytetach indywidualności profesora i indywidualność studenta. Uniwersytet stał się miejscem zdobywania wiedzy (rozumianej jako towar) a nie namysłu nad wiedzą i sposobem jej przekazywania. To co niegdyś było podstawą wykształcenia jako takiego, zostało zmarginalizowane na rzecz zdobywania wiedzy praktycznej, nakierowanej na sukces i zysk materialny. Pojawia się też - kosztem wykształcenia ogólnego - tendencja do szybkiej specjalizacji kierunkowej, najlepiej od pierwszego roku studiów. Mistrzowie nie są potrzebni, stanowią tylko element systemu pomiędzy egzaminem wstępnym na studia a otrzymaniem dyplomu. Bezpośrednia relacja często zostaje zastąpiona biurokracją, a coraz większe znaczenie uzyskują sposoby i procedury uniwersyteckiego administrowania. Rola nauczyciel akademickiego jest współcześnie coraz trudniejsza, bowiem otoczenie wciąż chce w nim widzieć omnibusa, który wszystko wie, rozumie i potrafi, a administracja uniwersytecka oczekuje sprawnego wypełniania akademickich powinności urzędowych.

Nadal jednak wokół wybitnych osobowości mistrzów skupiają się uczniowie. Możliwe jest to dzięki powtórnemu przeniesieniu kontaktów na odformalizowaną płaszczyznę np. do kół naukowych. Odbudowanie starej relacji mistrz-uczeń może być niepowtarzalną receptą na przełamywanie kryzysu w nauce, kulturze i życiu społecznym.

\section{Mistrz - uczeń: Szczególna relacja}

Idea kształcenia uniwersyteckiego i idea działania kół naukowych sprowadza się do poszukiwania mistrzów. Ten kto znalazł swojego mistrza znalazł ścieżkę dalszych samodzielnych poszukiwań naukowych i mentora, który pomoże mu rozwiązywać dylematy w chwilach zwątpienia. Jak ważny jest mistrz dowiadujemy wtedy, gdy piszemy pod jego kierunkiem pierwsze samodzielne prace. Często $w$ takich właśnie sytuacjach studenci dostrzegają w swoich wykładowcach autorytety o dużym doświadczeniu opartym na wiedzy, zdolnościach i mądrości. Jest to moment, w którym rodzą się szczególne relacje między mistrzem i adeptem. Przyswajanie unikalnej wiedzy, naśladowanie postępowania i wsłuchiwanie się we wskazówki mistrza formuje określone umiejętności ucznia i tworzy interakcję opartą na zaufaniu i poczuciu wspólnoty w poszukiwaniu naukowej prawdy. Warto podkreślić, iż powstają-

${ }^{16}$ Rozważania na ten temat patrz: Marulewska K.: O istocie mistrzostwa „Dialogi Polityczne" 2007 nr 7, s. 27-39 [online]. www.dialogi.umk.pl/archiwum/7/04_marulewska.pdf [data dostępu: 30.11.2012]. 
cy w ten sposób rodzaj autorytetu nie ma charakteru emocjonalnego, bowiem nie wynika z obawy, czy lęku wobec nauczyciela. Relacja ta nie jest także wynikiem uznania dla stanowiska bądź funkcji wykładowcy ${ }^{17}$. Autentyczność tej interakcji stanowi podstawę, na której opiera się europejska koncepcja uniwersytetu oraz paradygmat współczesnych studiów wyższych.

Niezbędnym warunkiem budowania wszelkich relacji jest komunikowanie. Fascynujące odkrycia niejednokrotnie zachwycają tylko specjalistów. Wysoka specjalizacja nauki prowadzi do nadmiernej formalizacji i normalizacji języka, poprzez co tzw. naukowość kojarzy się z niedostępnością. Tymczasem przecież popularyzacja nauki może sprawić, że zawód naukowca stanie się marzeniem wielu młodych ludzi. Noblista, John Steinbeck, poruszył kiedyś ważną kwestię komunikatywności języka naukowego. Zanotował, że tylko „małostkowi i nadęci ludzie przeciwni są temu, co nazywa się popularyzacją, a przez co rozumieją pisanie w sposób jasny i zrozumiały dla czytelnika, który nie jest obeznany ze sztuczkami i rytualnymi kodami. Chyba nie ma wielkiego naukowca, który nie potrafiłby podyskutować z dzieckiem. A może to przeciwnicy jasności nie mają nic do powiedzenia, niczego nie dostrzegają i nie mają wyraźnego obrazu nawet własnej dziedziny"18 - pytał Steinbeck pokazując hermetyczność i nieprzystępność współczesnego języka naukowego.

Historia nauki to historia wybitnych mistrzów, także w badaniach bibliologicznych. W miejscu, w którym jesteśmy zaczęła się historia polskiej bibliologii uniwersyteckiej. To właśnie tutaj, w Katedrze Bibliotekoznawstwa i Informacji Naukowej UŁ, prof. Jan Muszkowski (1882-1953) przeprowadził pierwszą w Polsce habilitację w zakresie nauki o książce (Adam Łysakowski, 1948) oraz promocje pierwszego doktoratu z tej dyscypliny (Karol Głombiowski, 1952). Wielu wybitnych profesorów prowadziło tutaj prace naukowe i poszerzało perspektywy badawcze nauki o książce. Do najwybitniejszych w historii należeli: prof. Helena Więckowska (1897-1984), prof. Bolesław Świderski (1917-1998), prof. Janusz Dunin-Horkawicz (1931-2007) ${ }^{19}$. Nie wszystkie wydarzenia o charakterze instytucjonalnym mają znaczenie dla nauki jako takiej. W bibliologii jednak ich waga w ostatnich dziesięcioleciach była doniosła, bowiem druga połowa XX wieku to czas przemieszczania się statusu nauki o książce w przestrzeń wiedzy akademickiej i zdobywania po-

${ }^{17} \mathrm{Na}$ temat pedagogicznego pojęcia autorytetu zob.: Milgram S.: Postuszeństwo wobec autorytetu, Kraków 2008.

${ }^{18}$ Steinbeck J.: Dziennik z Morza Corteza, przeł. A. Żukowska-Maziarska. Warszawa 2006, s. 82.

19 Więcej na temat historii i badań Katedry zob.: http://www.kbin.uni.lodz.pl/ kbin/index.php/o-katedrze/historia-katedry [data dostępu: 30.11.2012]. 
la intelektualnego (suwerenności), w znaczeniu takim, o jakim pisał Pierre Bourdieu ${ }^{20}$.

\section{Dążenie do osobistego mistrzostwa}

Czym powinna być współcześnie praca w kole naukowym? Czy tylko poszukiwaniem mistrza i opieraniem się na jego autorytecie? Nie, to byłoby zbyt mało. Wzajemność relacji pomiędzy uczniem a mistrzem nie polega na prostym czerpaniu i dawaniu. Ten typ sytuacji budzi skojarzenia z pojęciem „horyzontu” Hansa-Georga Gadamera i z poszukiwaniem horyzontu jako takiego $^{21}$ : „Horyzont - pisał współtwórca XX-wiecznej hermeneutyki filozoficznej - to krag widzenia, który obejmuje i ogrania wszystko, co jest widoczne z pewnego punktu. W odniesieniu do myślącej świadomości mówimy więc o [...] możliwości poszerzania horyzontu, otwierania nowych horyzontów itd. [...] Kto nie ma żadnego horyzontu, ten nie widzi wystarczająco daleko i dlatego przecenia to, co leży w pobliżu niego. Mieć horyzont natomiast oznacza wolność od ograniczenia do tego, co najbliższe, i możliwość wyglądania poza to. Kto ma horyzont, umie trafnie ocenić co do bliskości i dali, wielkości i małości znaczenie wszelkich rzeczy w tym horyzoncie",22.

Praca studencka w kołach naukowych to także praca nad samym sobą. Praca nad tzw. mistrzostwem osobistym, rozumianym jako dyscyplina uczenia się i osobistego rozwoju. Amerykański teoretyk, Peter M. Senge, wprowadził i upowszechnił pojęcie „organizacji uczących się” (OUS), czyli takich, które ciagle rozszerzają swoje możliwości i kreują własną przyszłość. Uniwersytet jako uporządkowany system, w którym poszczególne części przyczyniają się do sukcesu całości może być - w myśl amerykańskiego badacza - traktowany jako dość reprezentatywna „organizacja ucząca się”. Dodatkowo wewnętrzne powiązania i zależności decydują tu w sposób szczególny o wspólnym celu działania uniwersytetu.

${ }^{20}$ Zagadnienie suwerenności dyscyplin w ujęciu P. Bourdieu analizowano w polskiej literaturze naukowej w publikacji: Witkowski L.: Praca socjalna i profesjonalizm pedagogiczny. O zarzadzaniu humanistycznym: miedzy filozofia, edukacja i pedagogika społecznq. Łódź 2010, s. 186-187. Warto także zwrócić uwagę, że swoisty model relacji mistrzowskiej bibliotekarza i czytelnika został opisany w artykule: Pietrzak M. : Bibliotekarz i czytelnik a relacje mistrz-uczeń [W:] Ksiqżka, biblioteka, informacja $w$ kręgu kultury $i$ edukacji, red. E.B. Zybert i D. Grabowska, Warszawa: Wydawnictwo Stowarzyszenia Bibliotekarzy Polskich, 2008, s. 230-241.

${ }^{21}$ Gadamer H-G.: Prawda i metoda. Zarys hermeneutyki filozoficznej. Przeł. B. Baran, Warszawa: Wydawnictwo Naukowe PWN, 2004, s. 414-416.

22 Tamże, s. 415. 
Jednym z podstawowych warunków funkcjonowania OUS jest dążenie do „mistrzostwa osobistego" ${ }^{23}$. Czym więc jest to mistrzostwo osobiste? Według Senge, jest to stan napięcia twórczego, w którym stawiane przed człowiekiem zadania podsycają jego naturalną chęć pokonywania siebie i uczynienia ze swojego życia przedmiotu twórczości. To coś więcej niż kompetencje i umiejętności - to ciagły rozwój duchowy i kreatywna postawa wobec świata ${ }^{24}$.

Działanie w myśl idei zdobywania mistrzostwa osobistego nie jest jednak dążeniem do osiagnięcia określonego stanu, ale procesem ciągłego doskonalenia swojej gotowości do pracy, postrzegania rzeczywistości i dostosowywania myślenia do zmieniających się wciąż warunków otoczenia.

Ten specyficzny mistrzowski trening daje szczególny rodzaj biegłości, którą nabywa się w toku ćwiczeń. Obejmuje ona zarówno praktyczne umiejętności zawodowe jak i dyspozycje moralne pozwalające systematycznie wytyczać cele i kreować wizję swojego życia ${ }^{25}$. W konsekwencji oznacza to traktowanie pracy w kategoriach sztuki i całkowite zaangażowanie w to, co się robi i do czego się dąży ${ }^{26}$.

Uniwersytet jako organizacją korporacyjna, w tradycyjnym tego słowa znaczeniu $^{27}$, wciąż wspina się na szczyty doskonałości dzięki podtrzymywaniu wśród studentów i uczonych specyficznego napięcie twórczego prowadzącego do odkryć i realizacji najśmielszych planów.

\section{Zakończenie}

Prawie 100 lat temu Max Weber, podczas wykładu Wissenschaft als Beruf wygłoszonego w Monachium 7 listopada 1917 roku, określił kształcenie się naukowe na uniwersytecie jako ,zajęcie duchowo-arystokratyczne”, niedostępne każdemu, nacechowane lotnością i wzniosłością. Aby zajmować się

\footnotetext{
${ }^{23}$ Pozostałe to: modele myślowe, wspólna wizja, zespołowe uczenie się, myślenie systemowe.

${ }^{24}$ Więcej na ten temat zob.: Senge P. M.: Piata dyscyplina. Teoria i praktyka organizacji uczacych się, przeł. H. Korolewska-Mróz. Warszawa: ABC, 1998.

${ }^{25}$ Tamże.

${ }^{26}$ Rozwijanie mistrzostwa osobistego polega na przyjęciu twórczej, nie reaktywnej, postawy wobec świata. Pierwszym ważnym krokiem na drodze mistrzostwa osobistego jest określenie tego co jest dla nas ważne, do czego dążymy i co chcielibyśmy osiągnąć. Drugim diagnoza stanu obecnego, precyzyjne dostrzeganie otaczającej nas rzeczywistości, niezbędne dla oceny stanu faktycznego i stwierdzenie, na ile rzeczywistość rozmija się z naszymi aspiracjami, marzeniami. Luka pomiędzy naszą wizją a rzeczywistością kreuje twórcze napięcie, które mobilizuje do działania. więcej na ten temat zob. też: http://www.exbis.pl/vademecum/vademecum.php?dzial=40 [data dostępu: 30.11.1012].

${ }^{27}$ Łac. corporatio oznacza: związek; połączenie części.
} 
nauką - pisał Weber - trzeba posiadać wewnętrzne powołanie, ponieważ tylko „czynności, które można wykonać z pasją, są dla człowieka jako człowieka cokolwiek warte" ${ }^{28}$. W związku z tym - podkreślał myśliciel - nauka graniczy ze sztuką i potrzebuje natchnienia. Nie jest ,zadaniem rachunkowym, czymś, co niczym $\mathrm{w} »$ jakiejś fabryce«, produkowane jest przez zimny intelekt w laboratoriach czy statystycznych kartotekach [...]. To jednak, czy ktoś ma nauko-

wy pomysł, zależy od nieznanych wyroków losu, a poza tym od talentu"29. Należy jednak pamiętać, że środowisku naukowemu, podobnie jak innym grupom zawodowym, nieobce są słabości: uleganie naciskom, osłabienie krytycyzmu wobec przedstawicieli własnej grupy interesów, obrona przestarzałych paradygmatów, na których oparty jest osobisty sukces.

Na koniec, jako honorowy opiekun Studenckiego Koła Naukowego Bibliotekoznawców UŁ, chciałbym za Maxem Weberem podkreślić to co najistotniejsze: wzniosłość, natchnienie i pasja to najważniejsze cechy badacza, niezależnie od jego stopnia naukowego i wieku. Poszukujmy swoich mistrzów i pracujmy nad własnym mistrzostwem indywidualnym!

\section{Bibliografia}

1. Bloom A.: Umyst zamknięty. O tym, jak amerykańskie szkolnictwo wyższe zawiodto demokracje $i$ zubożyto dusze dzisiejszych studentów, przekł. T. Bieron. Poznań: Zysk i S-ka Wydawnictwo, 1997. - ISBN 83-7150-148-X

2. Gadamer H-G.: Prawda i metoda. Zarys hermeneutyki filozoficznej. Przeł. B. Baran, Warszawa: Wydawnictwo Naukowe PWN, 2004. - ISBN 978-83-01$14230-8$

3. Katedra Bibliotekoznawstwa i Informacji Naukowej UŁ [online]. Dostępny w Internecie: http://www.kbin.uni.lodz.pl/kbin/index.php/o-katedrze/historiakatedry [data dostępu: 30.11.2012]

4. Kotarbiński T.: Sprawność i bład (z myślq o dobrej robocie nauczyciela). Warszawa: Państwowe Zakłady Wydawnictw Szkolnych, 1966.

5. Ksiqżka, biblioteka, informacja w kręgu kultury i edukacji. Red. E.B. Zybert i D. Grabowska, Warszawa: Wydawnictwo Stowarzyszenia Bibliotekarzy Polskich, 2008. - ISBN 978-83-61464-04-4

6. Ladorucki J.: Koło naukowe jako szkota twórczego dziatania [W:] Historia $i$ wspótczesność w badaniach bibliologicznych. Red. J. Konieczna. Łódź: Ibidem, 2007, s. 185-189

7. Ladorucki J.: Studenckie Koło Naukowe Bibliotekoznawców Uniwersytetu Łódzkiego w latach 2000-2008 [W:] Tradycyjne i nowoczesne bibliotekarstwo

${ }^{28}$ Weber M.: Nauka jako zawód i powołanie [W:] Tenże: Polityka jako zawód i powołanie, przeł. A. Kopacki, P. Dybel, Kraków : Społeczny Instytut Wydawniczy „Znak” ; Warszawa : Fundacja im. Stefana Batorego, 1998, s. 117.

${ }^{29}$ Tamże, s. 118. 
$w$ oczach studentów informacji naukowej $i$ bibliotekoznawstwa: materiały z I ogólnopolskiej konferencji naukowej „Biblioteka: obiekt - idea wczoraj, dziś, jutro”, (Łódź, 18-19 maja 2007 r.) i I ogólnopolskiej konferencji studenckich kót naukowych „Elektroniczne oblicze biblioteki”, (Lublin, 11 kwietnia 2008 r.). Red. J. Ladorucki i R. Malesa, Kraków: AT Group, 2009, s. 11-20

8. Marulewska K.: O istocie mistrzostwa „Dialogi Polityczne” 2007 nr 7, s. 2739 [online]. Dostępny w Internecie: www.dialogi.umk.pl/archiwum/7/04_marulewska.pdf [data dostępu: 30.11.2012]

9. Witkowski L.: Praca socjalna i profesjonalizm pedagogiczny. O zarzqdzaniu humanistycznym: miedzy filozofia, edukacja i pedagogika społecznq. Łódź: Wydawnictwo Wyższej Szkoły Edukacji Zdrowotnej i Nauk Społecznych, 2010. ISBN 978-83-61095-25-5

10. Mistrz - uczeń: wyobrażenia czy rzeczywistość czyli o tworzeniu szkót naukowych. Oprac. i wybór E.Marynowicz-Hetka. Łódź: Łódzkie Towarzystwo Naukowe, 1997. - ISBN 83-85879-98-6

11. Milgram S.: Postuszeństwo wobec autorytetu. Kraków: Wydawnictwo WAM, 2008. - ISBN 978-83-7318-930-0

12. Oficjalna strona Uniwersytetu Jagiellońskiego [online]. Dostępny w Internecie: http://www3.uj.edu.pl/alma/alma/26/01/35.html [data dostępu: 30.11.2012]

13. Oficjalna strona Uniwersytetu Łódzkiego [online]. Dostępny w Internecie: http://www.uni.lodz.pl/ouni/misja [data dostępu: 30.11.2012]

14. Pietrzak M.: Bibliotekarz i czytelnik a relacje mistrz-uczeń [W:] Ksiażka, biblioteka, informacja $w$ kręgu kultury i edukacji, red. E.B. Zybert i D. Grabowska, Warszawa: Wydawnictwo Stowarzyszenia Bibliotekarzy Polskich, 2008, s. 230-241

15. Senge P.M.: Piqta dyscyplina. Teoria i praktyka organizacji uczacych się, przeł. H. Korolewska-Mróz. Warszawa: ABC, 1998. - ISBN 83-87286-52-4

16. Starnawski J.: Uniwersytet światyniq wiedzy. Łódź 2007. - ISBN 83-85925-54-6

17. Steinbeck J.: Dziennik z Morza Corteza, przeł. A. Żukowska-Maziarska. Warszawa: „Bellona”,, 2006. - ISBN 83-11-10350-X

18. Strona Towarzystwo Biblioteki Stuchaczów Prawa UJ [online]. Dostępny w Internecie: http://www.tbsp.pl/?link=onas [data dostępu: 30.11.2012]

19. Szaniawski K.: O nauce, rozumowaniu i wartościach. Warszawa: Wydawnictwo Naukowe PWN, 1994. - ISBN 83-01-11167-4

20. Weber M.: Nauka jako zawód i powołanie [W:] Tenże: Polityka jako zawód i powołanie, przeł. A. Kopacki, P. Dybel. Kraków: Społeczny Instytut Wydawniczy „Znak”; Warszawa: Fundacja im. Stefana Batorego, 1998. - ISBN 83-7006779-4

21. Witkowski L.: Praca socjalna i profesjonalizm pedagogiczny. O zarzqdzaniu humanistycznym: miedzy filozofia, edukacja i pedagogika społeczna. Łódź: Wydawnictwo Wyższej Szkoły Edukacji Zdrowotnej i Nauk Społecznych, 2010. ISBN 978-83-61095-25-5

22. Zieliński E. I.: Rola mistrza i szkoty w filozofii. [W:] Spór o rozumienie filozofii. Zadania wspótczesnej metafizyki. Red A. Maryniarczyk, K. Stępień. Lublin: Polskie Towarzystwo Tomasza z Akwinu, 2009. - ISBN 978-83-60144-26-8 